\title{
Social Causes of Juvenile Delinquency: The Case of Axum Correctional and Rehabilitation Center, Northern Ethiopia.
}

\author{
Tekelwoyni Tesfamichael ${ }^{a}$, Tesfaye Zeleke (Assistant Professor in Sociology) ${ }^{b}$, Yonas kidane ${ }^{c}$ \\ ${ }^{a}$ Gondor University Department of Sociology, School of Sociology and Social Work, College of Social Science and Humanities, Ethiopia \\ ${ }^{\mathrm{b}}$ Assistant Professor in Sociology, Addis Ababa University, College of Development Studies, Center for \\ Environment and Development, Tourism Program \\ ${ }^{\mathrm{C}}$ College of Environmental Science and Engineering.Tongji University, Shanghai 200092, P.R. China. \\ DOI: 10.29322/IJSRP.10.07.2020.p10356 \\ http://dx.doi.org/10.29322/IJSRP.10.07.2020.p10356
}

\begin{abstract}
The purpose of this study was to explore the Social Cause of Juvenile Delinquency at Axum Correctional and Rehabilitation Center, Northern Ethiopia. It was to investigate the demographic and the socio-economic statuses of juveniles. It also investigated the type of different offenses committed by juveniles. To this end, the study was carried out using mixed research method. Structured questionnaires and key informant interviews used as tools of data collection. The study involved 80 inmates selected by systematic random sampling technique from a total list of 155 inmates. The study found that $96.25 \%$ of respondents belong to the age between 13 and 17 years old. About $86.25 \%$ of the respondents were males; and $68.75 \%$ of the juvenile delinquents were from rural areas and poor family backgrounds. The study sample was also characterized by a low level of education. The results of the study are congruent with what exists in literatures indicating economic problems or poverty is the major cause for many juvenile's involvements in crimes. It was also found that $26.25 \%$ of the juveniles were institutionalized out of peer influences. Besides, other social factors including dysfunctional families, large family size, rural urban migration, and quality in family relationships, lack of parental control and the availability of alcohol and, drugs in the neighborhood influenced these young into crime and delinquency. about the type of crime committed by the juveniles, the study revealed that theft and related crimes were mostly committed by a juvenile than any other offense.
\end{abstract}

Index Terms- Axum correction center, Juvenile Delinquency, Social causes

\section{INTRODUCTION}

\section{$\mathrm{J}$} 1.1. Back ground

uvenile delinquency is a complex social problem that significantly impacts all members of society and processes of a social structure. Delinquency refers to a set of behaviors that are not in line with the collective practices and/or ethics of the dominant social group. Essentially, these behaviors deviate from societal norms and more specifically they violate established criminal codes and laws (Georges, 2009:56).
Globally, crime patterns are changing. Offenders are increasing in number, the youngsters are getting involved and violent crimes are becoming more common. Also, our life, our views of the world and our ways of knowing about crime have undergone considerable change with the changing patterns of crime (Edwin, 2006). The roots of such violence may not be clearly understood but declining income and work opportunities, and the consequent frustration, particularly for youth are important factors (Azeb, 2009). Violence, crimes and anti-social behaviors were consequences of social inequality, social exclusion and lack of institutional and social protection (Sisay, 2015).

The most important causes and conditions for juvenile delinquency are described from economic and social factors. Socio-economic instability is often linked to persistent unemployment and low incomes among the young, which can increase the likelihood of their involvement in criminal activity. In terms of social factors, delinquent behavior often occurs in social settings in which the norms for acceptable behavior have broken down (MesafintAdal, 2009).

On the other hand, an important aspect of the socialization process and a cause of delinquency is the quality and process of interaction between parent and child. If communication breaks down at any point, it could lead to delinquent behavior. In addition to that, the absence of family as a unit could affect childhood and how children socialized. Where the family fails, other socializing agencies will take on an increasing role in a child's life (Wickliffe \& Joseph A, 2013). The significant factor of juvenile crime is also the increasing number of dysfunctional families. Juveniledelinquency rates are twice as high for youngsters from singleparent homes as for those in normally functioning families. Children in single-parent families are taken less care of and thus have feelings of being neglected, discriminated and isolated. The lack of parental love makes them hostile and cynical towards society (Benekos \& Merlo, 2010).

In Asian countries, juvenile crime and delinquency are largely urban phenomena. As it is true elsewhere, young people constitute the most criminally active segment of the population. The financial crisis that hit some countries in East and Southeast Asia created economic stagnation and contraction, leading to large-scale youth unemployment and drug traffickers frequently recruit adolescents to serve in this industry, and many become 
addicted to drugs while involved in this criminal activity (Jarjoura, et al., 2012). Hunte (2014) notes that long-term unemployed youths are at high risk of social exclusion, feel socially isolated and economically excluded. Unemployment threatens the overall integration of the youth into a society that may lead to the criminal offence. Russell, et al., (2009) observe that crime among the youth is associated with the current level of youth unemployment and the annual changes in the rate of youth unemployment.

In Latin America, the young have been the hardest hit by the economic problems linked to the extremely high unemployment rates prevailing within this group. Juvenile delinquency is particularly acute and is often associated with the problem of homelessness among children and adolescents create environments that are conducive to crime and delinquency (Ignacio, 2013).

In the Middle East, there is less indication that serious problems with juvenile delinquency exist. However, affluent nations such as Saudi Arabia and the United Arab Emirates have more problems with juvenile offenders than do other nations in the Middle East (Ramiro, M., \& Matthew, 2012).In these countries, delinquency occur in connection with migrants seeking employment and it linked to factors such as continued urbanization, rapid changes in the economy, and the increasing heterogeneity of the population. The conflict between traditional Arab-Islamic values and modern views imported from other areas of the world seems to be a common problem for countries in this area of the world (Siegel, et al., 2011).In Eastern European countries such as Russia, families are becoming more dysfunctional. Indeed, the number of parents who are deprived of their childrearing rights is increasing annually (Wood,et al., 2009).Parents are often alcoholics, drug addicts, and they have criminal backgrounds (Sandstrom, 2012). Factors such as unemployment and low family income are the main contributors to juvenile delinquency in many parts of this region. There are few, if any, social services in these countries, which creates a dismal picture for youth (Simoes, 2015).

Throughout the African continent, delinquency tends to be attributed primarily to poverty, malnutrition, and unemployment. These factors are the result of marginalization of juveniles in the already severely disadvantaged segments of society (Warr, 2011). Rapid population growth has been experienced in Africa, and the population seems to be getting correspondingly younger over time. This is coupled with the fact that few new jobs are developed in Africa, which has resulted in half of all families living in poverty and juvenile delinquency is on the rise, with the primary offenses being theft, robbery, smuggling, the abuse of narcotic substances, and drug trafficking among young offenders (Ojo, 2012).

According to Andergachew (2004) Ethiopia is one of the developing countries where the majority of the people live below the poverty line. Young people constitute the majority of the poor. Together with the rapid urbanization and the observation capacities of Ethiopian cities being very limited a large number of unemployed people roomed around city streets. Central Statistical Agency Survey (C.S.A, 2015) showed that the total unemployment rate for the youth (percentage of total labor force aged 15-24) is estimated to be 25 percent. It is inevitable for such people to be fertile ground for deviancy activities such as theft, robbery, burglary, and other similar crimes. This condition's is illustrated by the 2013 study of 90 prisoners which revealed that 57 of them were committed to prison pity theft (Bimal, 2013).

Drought and famine, armed conflict, destabilizations of family life have left millions of children in Ethiopia without care and protection. These and other related socio-cultural factors have led to the abuse, neglect and/or mal-treatment of children in Ethiopia (Andergachew, 2004). According to Bimal(2013), the problems of juvenile delinquency are connected with the results of poor background, dysfunctional family, and influence of peer groups and poverty, which is considered to be the roots of problems and issues in the country, may not be eradicated easily. When poverty prevails, there would still be juvenile delinquents prowling all over the study area, Axum. This study, therefore, aims at exploring the social causes of juvenile delinquency in Axum Correctional and Rehabilitation Center. Specifically, the family relation and dynamics (dysfunctional families, quality in family relationships, lack of parental control, low family socio-economic status) and influence of external environment (Peer influence, school influence, rural -urban migration, the availability of alcohol, drugs in the neighborhood).

\subsection{Justification of the Study}

Now days, serious and violent crimes have been being committed by juveniles in an alarming rate in developing countries. In addition to their involvement in violent person and property crime, juveniles are committing increasing number of alcohol and narcotic or drug related offences (Paylor, 2010). Economic deterioration, poverty, uncontrolled and unplanned migration from rural to urban areas in search of better working condition exacerbated the problem of delinquency (Sisay, 2015). According to Federal Police Commission, of 182,169 total numbers of criminals reported in Ethiopia for 2012/13, 32,133 were of juveniles aged 9-17 years and of 211,302 criminals for 2013/14, 37,233 were juvenile delinquents aged 9-17. This reflects an overall increment both in number of juveniles and adults criminals in the year $2013 / 14$ by $13.69 \%$ and $10.93 \%$ respectively as compared to $2012 / 13$. The national crime statistics compiled by the Federal police commission in 2015 for the year 2016 has shown that 311,202 crimes were reported to police throughout the country, juveniles aged 9-17 accounted for $21 \%$ of total crimes. In the same way, of 127,989 crimes were reported throughout the Tigray region to the police for the years 2012/13, 2013/14, 2014/15,juveniles accounted for 15 percent of total offenses and in the same three years of 125,115 criminals, 18,050 were juvenile offenders in the region (Tigray Police commission, 2014).Moreover, the national crime statistics report has indicated that the Tigray regional state accounts for $13 \%$ of the total crimes reported to the police in the entire country; and out of the Tigray region share $12.8 \%$ of all criminals in the country, $3.2 \%$ were juvenile offenders in 2014/15.This indicates that the Tigary region is one of the crime prone regions in the country. Data compiled in 2016 by Axum Police office shows that there were a total of 3,500 offences from the year 2012/13, 2013/14, 2014/15 committed by child offenders. Among these offences $29.5 \%$ of the children were from age 15 to 17 , whereas $3.8 \%$ total offence during the three years were committed by children of age $9-14$ and $51.7 \%$ by the 18-30 age group.

For the first age-group (9-15), the total number of offenders has generally tended to rise through consecutive years. For 
example, the number of offenders in 2012/13 and 2013/14 was 1155 and 1803 respectively with $38.96 \%$ increment. Comparison between 2012/13 and 2014/15 shows even a larger increment which was 53.7\%. Based on the 2007 census report of Axum population size, the prevalence rate of offenders for this age group was 146 per 100,000 which indicate that out of every 100,000 people in this age category 146 are offenders. Whereas this age group shares about $12 \%$ of the total population of the city, its share in offenders' population is only $1.7 \%$. It indicates that compared to others, this age group is the least prone to criminal behavior if we assume that there is no recording bias by the police.

The number of offenders in the second age group (16-18) steadily increased in 2012/13 and 2013/14 and then declined in 2014/15.This age group comprises about $15 \%$ of the city population but its total share within criminal population is nearly $27 \%$. Its criminal prevalence rate is 4343 per 100,000 which is nearly sixteen times of (9-15) age group. This age group is the most prone to criminal activities (Sisay, 2014).However; data regarding age is not reliable due to the absence of compulsory vital registration system. Nevertheless, juvenile delinquency is the root for more organized and sophisticated crimes that costs a very strong activity in order to tackle it. However, it is often overlooked in the study area. The problem is explained as not challenging enough in relation to the other economic or social difficulties people confront. Thus, the attention of the police is emphasized only in ordinary crime and the problem has never been given full attention. As a result, juvenile crime and delinquency are becoming social problem in Axum town. There are some previous researches carried out on the juvenile delinquency related topics. For instance, Selamawit (2014) studied the lived experience of delinquents and young offenders in the case of Addis Ababa police commission prisoners. It was a qualitative study and the result indicated that the causes of delinquency include mental illness, peer pressure, unemployment, and separation of family (divorce), financial problem and addiction. On the other hand, Habtamu Mamo (2007) also assessed the pattern and trends of crime against the women in prison. The study explains the case of delinquency in relation with genetic factor and socialization. However, the two studies, fail to indicate clear benchmark about the driving factors of offence.

Similarly, Bimal (2013) undertook a quantitative study to explain the case of delinquency in relation with each level of the social structure, such as social institutions, social groups and organizations, and interpersonal relations. In general, these limited studies are related with my research in many ways. The variables they used include family relation and dynamics (dysfunctional families, quality in family relationships, lack of parental control, low family socio-economic status) and influence of external environment (Peer influence, School influence, rural -urban migration, the availability of alcohol and, drugs in the neighborhood) were covered by the previous studies. But, all of the above mentioned literatures used either qualitative or quantitative study. In the case of this study, however, the investigator believes that the best result mostly comes from the careful and selective use of both methods and triangulating them as long as there are variables to be measured and explored.

Cognizant to the prevailing research gaps, this study aimed at investigating the social factors that contribute to juvenile delinquency in Axum Correctional and Rehabilitation Center.

\subsection{Objective of the study}

- To investigate demographic characteristics of juvenile delinquents

- To identify the social causes of juvenile delinquency in the study area

- To investigate the socio-economic statuses of juvenile delinquents

- To describe the type of different offenses committed by juveniles

\section{Materials AND MethodS}

\subsection{Study Area}

Axum is situated in central administrative zone of Tigray in the high land of the Tigray regional national state in the northern tip of the Ethiopian Plateau at $14^{\circ} 07^{\prime}$ North latitude and $38^{\circ} 44^{\prime}$ East Longitude at an altitude of $2100 \mathrm{~m}$ above sea level. Geographically Axum is located west of Adwa, East of Wukro Maray, North of EdagaSelus and south of Rama at $1041 \mathrm{Km}$ distance from Addis Ababa. Regarding the climatic conduction, it is conducive for all activities which is "Weynadega" with mean annual temperature ranges' between $9.3^{\circ} \mathrm{C}$ and $29.8^{\circ} \mathrm{C}$ whereas the mean annual rainfall ranges between 85.9 ML and 428.1ML (Metrological service agency Mekelle, 2014). Administratively the town is structured into four kebeles of Hawelti, Hayelom, Kindya and Maebel with a total population of 44,647 out of this number 21,778 and 25, 108 are males and females respectively with the total house hold head of 13,790 out of this number of total house hold heads 6,405 and 7,385 are men and females respectively. The annual growth rate of the populations is $2.5 \%$ almost less than by $0.7 \%$ from the national average. The source of livelihood and backbone of Axum's economy are agriculture, tourism and trade respectively. At present, there are a lot of socioeconomic activities in Axum city like construction of international hotels \& multi-story buildings by the private sector.

\subsection{Research Design}

A cross sectional study was conducted to collect the necessary information on the research problem. This study is an institutional based study that was carried out among inmates in Axum Correctional and Rehabilitation Center, where convicted juveniles undergo the process of rehabilitation and correction and it was employed a mixed approach. It can be argued that the reason for combining quantitative and qualitative methods is to capitalize on the strengths of the two approaches and to compensate for the weakness of each approach. Considering this point of view on the combination of the methods, combinations of quantitative and qualitative approaches were selected for the research upon which this thesis was based. Both primary and secondary data sources were used in the study. The primary data was collected from juvenile delinquents found at Axum Correctional and Rehabilitation Center, police investigators, judges from courts as well as selected parents of the juvenile delinquents using questionnaires and, key informant interviews.

Secondary sources: In addition to the primary data that was collected by the investigator from the study participants using different research methods, the secondary data was also collected from different sources, such as written documents, police reports and journals, books, published and unpublished materials. The 
total population was comprised of 155 juvenile delinquents. Out of this population, a sample size of 87 respondents was taken as a suitable sample size using the formula proposed by Kothari (2004) and the study used a systematic random sampling technique.

The quantitative analyzing method was used to analyze the quantifiable data of socio-demographic characteristics, social factors that contribute to juvenile delinquency, socio-economic statuses of juveniles, and different offenses committed by juveniles. Quantitative data was analyzed using Statistical Package for Social Sciences (SPSS) and the result was presented in tables.

Qualitative data obtained through interviews were analyzed by using content analysis. It followed the following steps: identification of the main themes, assignment of codes to the main themes, and classification responses under the main themes. Finally, the information from key informants was categorized into themesthat were used to cement the findings of the study.

\section{RESULT AND DISCUSSION}

Table 1: Sex distribution of the Respondents

\begin{tabular}{lll}
\hline Sex & Number of Respondents & Percentage \\
\hline Male & 69 & 86.25 \\
Female & 11 & 13.75 \\
Total & 80 & 100
\end{tabular}

Source: Own Survey, 2017

As indicated in table 1, $69(86.25 \%)$ of the delinquents are males while the remaining a much smaller proportion of 11 (13.75 $\%)$ are females. The results imply that boys are involved in delinquency more often than girls. This resonates with findings by Weijters (2013) that males engage more in delinquent and criminal acts than females. even though adolescents, both male and female, are at great risk of becoming delinquents, the main perpetrators are male (Shaw, 2007:89). A study by Legal and Human Rights Centre (2012) revealed similar results of female crime rate being lower than that of males providing social and cultural reasons being the prima-facie reasons explaining their rate. This is clear from the following quotation from one key informant police inspector:

"......girls are involved in delinquency less often than boys because tighter controls exist for females both in the family and in their public lives, for example, adolescent girls are likely to be allowed less freedom to go out of the house and stay out than are their male counterparts. This limits the opportunities girls have to become involved in delinquent behavior ...."
Table 2: Distribution of Respondents based on Age group, Religion, Original premises and educational level

\begin{tabular}{|c|c|c|c|c|c|}
\hline \multirow{2}{*}{$\begin{array}{l}\text { S. } \\
\text { No. }\end{array}$} & \multirow{2}{*}{ Item } & \multicolumn{4}{|c|}{ Number of Respondents } \\
\hline & & Male & Female & Total & Percentage \\
\hline \multirow[t]{4}{*}{2} & $\begin{array}{l}\text { Age of the } \\
\text { delinquents } \\
\text { when they } \\
\text { join to the } \\
\text { institution }\end{array}$ & & & & \\
\hline & $9-12$ & 3 & - & 3 & 3.75 \\
\hline & $13-17$ & 66 & 11 & 77 & 96.25 \\
\hline & Total & 69 & 11 & 80 & 100 \\
\hline \multirow[t]{7}{*}{5} & $\begin{array}{l}\text { Religious } \\
\text { background }\end{array}$ & & & & \\
\hline & $\begin{array}{l}\text { Orthodox } \\
\text { Christian }\end{array}$ & 65 & 8 & 73 & 91.25 \\
\hline & Muslim & 4 & 3 & 7 & 8.75 \\
\hline & Protestant & - & - & - & - \\
\hline & Catholic & - & - & - & - \\
\hline & Others & - & - & - & - \\
\hline & Total & 69 & 11 & 80 & 100 \\
\hline \multirow[t]{5}{*}{6} & $\begin{array}{l}\text { Original place } \\
\text { or Premises }\end{array}$ & & & & \\
\hline & Rural & 48 & 7 & 55 & 68.75 \\
\hline & Urban & 19 & 3 & 22 & 27.5 \\
\hline & $\begin{array}{l}\text { Semi } \\
\text { Urban/Semi } \\
\text { Rural }\end{array}$ & 2 & 1 & 3 & 3.75 \\
\hline & Total & 69 & 11 & 80 & 100 \\
\hline \multirow[t]{7}{*}{7} & $\begin{array}{l}\text { The } \\
\text { educational } \\
\text { level of } \\
\text { respondents }\end{array}$ & & & & \\
\hline & Illiterate & 12 & 3 & 15 & 18.75 \\
\hline & $\begin{array}{l}\text { 1st cycle } \\
\text { (grade 1-4) }\end{array}$ & 11 & 2 & 13 & 16.25 \\
\hline & $\begin{array}{l}\text { 2nd cycle } \\
\text { (grade 5-8) }\end{array}$ & 46 & 6 & 52 & 65 \\
\hline & $\begin{array}{l}\text { High school } \\
\text { (grade } 9-10)\end{array}$ & - & - & - & - \\
\hline & $\begin{array}{l}\text { Certificate or } \\
\text { diploma }\end{array}$ & - & - & - & - \\
\hline & Total & 69 & 11 & 80 & 100 \\
\hline
\end{tabular}

Source: Own Survey, 2017

Table 2 indicates that the majority of the respondents were aged between 13-17 years (96.25\%) while $3.75 \%$ were aged between 9-12 years. It indicates that most of the delinquents were in age 13-17 years as it is also supported by the standard definition of the American Psychological Association that a juvenile delinquent is a person who is under age (usually below 18 Years). This clearly shows that the early adolescent period is the time when youngsters are highly delinquents compared to other periods 
of adolescents. This resonates with findings by Elliott and his colleagues (1985) that the level of adolescent involvement in delinquent acts-whether violent or nonviolent, serious, or minorgenerally peaks sometime between 15 and 17 years of age.

The juveniles who are the focus of this study needed parental care in terms of the provision of basic needs, strong bond and guidance. However, these findings implicate that socializing agent are inefficient in shaping and controlling youth behavior. Since juveniles are expected to be under the control and protection of their families and the wider social environment, such proneness to criminal behavior shows that their early socialization could have been negative and unsupportive.

Concerning religious background, 73 (91.25\%) are followers of Orthodox Christianity religion, whereas $7(8.75 \%)$ are Muslims. The majority $(91.25 \%)$ of delinquency acts are committed by Orthodox Christianity believers. The result attained was similar to the previous study conducted by $\operatorname{Bimal}(2013)$ that the magnitude of juvenile delinquency is more from orthodox Christianity than Islam and another reason is that in this particular locality the percent of the population is more from orthodox Christianity than Islam.

The table also reveals that $55(68.75 \%)$ of the respondent come from rural areas, whereas $22(27.5 \%)$ from urban areas. The remaining $3(3.75 \%)$ of the juveniles come from semi-urban /Semi-rural areas. The preponderance of most of the juveniles being from rural areas supports the classical theorists who opined that migrant youth are more delinquent than native-born adolescents. The results are supported by the existing empirical studies, Betelehem(2014) and Sisay (2015), who suggested that juveniles who come from rural areas are more likely to become involved in delinquency than their native-born counterparts.

The question of migrants was asked in order to know whether migrant youth are mostly involved in crimes than nativeborn adolescents, most of the key informants indicated that migrant youth are mostly involved in crimes.

The police inspector said,

“.....Axum's population has increased drastically because of the migration process....." people come in anticipation of a better life, which involves finding a job, but once life gets tough, they are forced into criminal activities.

Another key informant from especial representatives to juvenile delinquents at the correctional administration center noted that, migrants have had a higher rate of crime in the sense that jobless migrants turn to crime as a means of survival. Police inspector as a key informant has pointed out as follows

"......The trend of migration has been on the increase ever since by a situation created where everyone is free to move and settle anywhere, people have been drawn to the town with high hopes of finding employment, when chances of getting jobs narrow, these juveniles might be tempted to commit a crime to survive......"

One judge elaborated:
"Since everyone has a right to move and settle anywhere, many young people have decided to live in cities due to impoverished living conditions in rural areas and this has resulted in many social problems, some of which are unemployment and of course engaged in crime."

According to the above quotes, young people have come to Axum in search of better economic opportunities, but with few chances of meeting those expectations. Once they fail, those young turn to other ways of making a living and some of these ways such as theft have not been approved by society. Even though the general consistency in the aforementioned empirical results, further careful examination is needed due to the fact juveniles who have urban origin have better knowledge to escape from the site of the police. These results are consistent with those of Xi Chen \& Hua Zhong (2013), who suppose that the probability of migrant youth being caught committing a crime was much higher than the urban-born.

About educational level, the results in table 2 show that 13 $(16.25 \%)$ of the sampled young offenders were from the first cycle, whereas $52(65 \%)$ were from the second cycle and the remaining $15(18.75 \%)$ of respondents had never been to school at all. The figure indicated that young people in lower education levels were more likely to get involved with delinquency than those higher levels as none of the respondents had reached high school.

This finding is supported by Weijters (2013) who argued that, adolescents in lower secondary commit more delinquent acts. Also, Aoki (2010) mentioned that higher school attainment reduced the number of crime among young people since they have the legal/moral knowledge about the cost of criminal behavior. Likewise, juveniles who have low academic achievement at the age of 10,14 and 16 years old tend to commit criminal actions at the age of 18 years old (Herrenkohl, et. al., 2010). These statements indicate that having a good educational background reduces the risk of adolescents to be involved in any criminal activities. Bearing in mind that none of the respondents had reached high school, these findings implicate the extent to which they had lost their ground academically due to their delinquent behavior because it was expected that delinquent behavior would in most cases either delay or terminate school completion. The highest level of education attained by the respondents could indicate where they were in their academic ladder.

Information on the period of stay in the correctional center was also sought on grounds that how long a child was in the institution, table 3 presents a summary of this information:

The table shows the distribution duration of stay in the correctional and rehabilitation center by the juvenile. $81.25 \%$ of them had been in the institution for less than 2 years. Further, $11.25 \%$ of the juveniles had been at the center for between 2 years and 4 years. The remaining $7.5 \%$ of the respondents had been at the center for more than 4 years. 
Table 3: Period of Stay in the Correctional and Rehabilitation Center

\begin{tabular}{|l|l|l|l|l|l|l|}
\hline \multirow{2}{*}{ S. No. } & \multirow{2}{*}{ Item } & \multicolumn{4}{l|}{ Number of Respondents } & Percentage \\
\cline { 3 - 6 } & & Male & Female & Total \\
\hline 1 & Duration of Stay at the center & 57 & 8 & 65 & 81.25 \\
\hline 2 & Under 2 years & 7 & 2 & 9 & 11.25 \\
\hline 3 & 2 years to 4 years & 4 years \& above & 5 & 1 & 6 & 7.5 \\
\hline & Total & $\mathbf{6 9}$ & $\mathbf{1 1}$ & $\mathbf{8 0}$ & $\mathbf{1 0 0}$ \\
\hline
\end{tabular}

Source: Own Survey, 2017

In general, data on the juveniles' demographic aspect reveal that certain demographic characteristics such as being in the age group 13 to 17, being male, being from followers of Orthodox Christianity religion, being from a rural area and having a lower education are more related with delinquency than others.

\section{Social Causes of Juvenile Delinquency}

The study sought to understand the social causes of juvenile delinquency. Data was collected on social factors related to family relations and dynamics and influence of the external environment (such as Peer influence, school influence, rural-urban migration, the availability of alcohol and, drugs in the neighborhood).

\section{Family Relations and Dynamics}

Information was collected on marital status, educational and occupational status, estimated monthly income of the delinquent parents and quality parent-child relationships, lack of parental control, family size, as socioeconomic status and family factors that attribute to delinquency.

\section{Table 4: Marital, Educational and Occupational Status of the Delinquents Parents}

\begin{tabular}{|c|c|c|c|c|c|}
\hline \multirow[b]{2}{*}{ S.No, } & \multirow[b]{2}{*}{ Item } & \multicolumn{4}{|c|}{ Number of Respondents } \\
\hline & & Male & Female & Total & Percentage \\
\hline \multirow[t]{8}{*}{1} & \multicolumn{5}{|l|}{ Marital Status of the Delinquents' Parents } \\
\hline & Live together & 25 & 3 & 28 & 35 \\
\hline & Never married & - & - & - & - \\
\hline & Mother deceased & 4 & 2 & 6 & 7.5 \\
\hline & Father deceased & 5 & 3 & 8 & 10 \\
\hline & both parents deceased & 8 & 1 & 9 & 11.25 \\
\hline & Divorced or separated (but both still alive) & 27 & 2 & 29 & 36.25 \\
\hline & Total & 69 & 11 & 80 & 100 \\
\hline \multirow[t]{8}{*}{2} & \multicolumn{5}{|l|}{ Occupation of parents } \\
\hline & Government work & 2 & 1 & 3 & 3.75 \\
\hline & Private sector & 2 & 2 & 4 & 5 \\
\hline & Daily labor & 8 & 1 & 9 & 11.25 \\
\hline & Agriculture & 54 & 5 & 59 & 73.75 \\
\hline & Commerce / own business & 3 & 2 & 5 & 6.25 \\
\hline & Other & 0 & 0 & 0 & 0 \\
\hline & Total & 69 & 11 & 80 & 100 \\
\hline \multirow[t]{6}{*}{3} & \multicolumn{5}{|l|}{ Parental level of Education } \\
\hline & Illiterate & 31 & 3 & 34 & 42.5 \\
\hline & $1-8$ complete & 19 & 3 & 22 & 27.5 \\
\hline & 9-12 complete & 11 & 1 & 12 & 15 \\
\hline & Certificate & 4 & 2 & 6 & 7.5 \\
\hline & Diploma & 3 & 2 & 5 & 6.25 \\
\hline
\end{tabular}




\begin{tabular}{|l|l|l|l|l|}
\hline & Degree and above & 1 & 0 & 1 \\
\hline & Total & $\mathbf{6 9}$ & $\mathbf{1 1}$ & 1.25 \\
\hline
\end{tabular}

Source: Own Survey, 2017

As indicated in Table 4, out of a total of 80 delinquent children, $8(10 \%)$ were from father deceased family $6(7.5 \%)$ formed mother deceased family $9(11.25 \%)$ formed both mother and father deceased family, $29(36.25 \%)$ were from divorced or separated parents (but both still alive) and the rest $28(35 \%)$ were from the living together with family (unbroken home). From this data, one can easily note that the majority of $52(65 \%)$ of respondents came from homes whose parents had died, divorced, or separated parents (dysfunctional family). This confirms the statement of Price \& Kunz (2013) that children who live in homes with only one parent or in which marital relationships have been disrupted by divorce or separation are more likely to display a range of behavioral problems including delinquency, than children who are from two-parent families. It is interesting to note that a total of 28 or $35 \%$ of the delinquent children came from an intact family. This could be indicating the existence of weak interpersonal relationships within the family and its social control. Police from investigators, judges, correctional and rehabilitation center staffs held similar views that inappropriate family environment, ineffective parenting and unstable families led to delinquent behavior.

With regards to occupation, 59 (73.75\%) of the respondents' parents rely on agriculture whereas $3(3.75 \%)$ are government workers, $4(5 \%)$ are employed in the private sector, $9(11.25 \%)$ are daily laborers, and 5(6.25\%) engaged in their own business. This figure indicates that the majority of the respondents came from low-income families who involved mainly in agriculture. The finding is consistent with previous studies. Such as Sisay, (2014),
Harris, (2006 \& Mbuthia, 2013) who argued that children from the poor and working-class are much more likely to engage in delinquent behavior.

It was also found that their parents'/guardians' responses on interviewing about their source of income where the majority of them $(76.8 \%)$ expressed that they depended solely on subsistence agriculture. These results are in line with those of levels of education attained by parents and it proves that lack of education the respondents' parents leaving them with no option but to engage themselves in agriculture and daily labor.

Concerning the educational level of the delinquent parents, the study revealed that $42.5 \%$ of respondents' parents are illiterate and those who are in the range of 1-8 complete are accounted 22 (27.5\%) followed by those who are 9-12 complete accounted 12 $(15 \%)$. For those who have a certificate, diploma and degree and above cover $6(7.5 \%), 5(6.25 \%)$ and $1(1.25 \%)$ respectively. It could be concluded that the juveniles with parents with a low educational level have more probability to become delinquent than those parents who have higher educational achievement. This is because parents with a low educational level may not be as involved as should in their children's education. The result of this study affirms the opinion of Faraja (2014), who argued that the low education level of parents contributed to respondents being delinquents for the fact parents, did not know or experience the fruits of education thus failing to insist it to their children.

Table 5: Juveniles and their Leisure time

\begin{tabular}{|c|c|c|c|c|c|}
\hline \multirow[b]{2}{*}{ S. No } & \multirow[b]{2}{*}{ Item } & \multicolumn{4}{|c|}{ Number of Respondents } \\
\hline & & Male & $\begin{array}{l}\text { Femal } \\
\mathrm{e}\end{array}$ & Total & $\begin{array}{l}\text { Percentag } \\
\mathrm{e}\end{array}$ \\
\hline \multirow[t]{6}{*}{1} & \multicolumn{5}{|l|}{ How juveniles spent Most Time } \\
\hline & playing with friends & 46 & 3 & 49 & 61.25 \\
\hline & watching movies & 8 & 2 & 10 & 12.5 \\
\hline & visiting friends & 12 & 4 & 16 & 20 \\
\hline & assisting in various household tasks & 3 & 2 & 5 & 6.25 \\
\hline & Total & 69 & 11 & 80 & 100 \\
\hline \multirow[t]{6}{*}{2} & \multicolumn{5}{|c|}{ People with whom the juveniles spent Most Time } \\
\hline & Mothers & 32 & 3 & 35 & 43.75 \\
\hline & Grandmothers & 10 & 4 & 14 & 17.5 \\
\hline & Grandfathers & 7 & 2 & 9 & 11.25 \\
\hline & Fathers & 6 & 1 & 7 & 8.75 \\
\hline & Friends & 14 & 1 & 15 & 18.75 \\
\hline
\end{tabular}




\begin{tabular}{|l|l|l|l|l|l|}
\hline & Total & 69 & $\mathbf{1 1}$ & $\mathbf{8 0}$ & $\mathbf{1 0 0}$ \\
\hline
\end{tabular}

Source: Own Survey, 2017

To establish if the parents/guardians had a quality relationship with their children, the researcher sought to find out how they spent their time. The results implied that most juveniles spent their time mainly playing with friends $(61.25 \%)$, watching movies (12.5\%) and visiting friends (20\%). Quite a small minority $(6.25 \%)$ spent most time assisting in various household tasks (Table 5). This implies that they were away from home most of the time. Thus, they were hard with their parents/guardians. This echoes their parents'/guardians' responses on whether they had adequate time with their children where the majority of them (92.8\%) conceded to have had inadequate time. Lack of adequate time spent by parents/guardians with the child may have led to the loss of parental relationship and authority over adolescence. The influence may have been taken by the children's friends with whom they spent most of their time. If, for instance, these friends are deviants, then they are likely to adopt socially unacceptable behaviors.

This is consistent with findings by Steinberg (2012) that the influence of peers and their acceptance of delinquent behavior are significant, and this relationship is magnified when youth have little interaction with their parents. During the interview with informants also confirmed this. One delinquent parent would say:

".......I insisted that he stays at home, he would not hear of it. He was always away with his friends. I think he has copied the father because he too leaves in the morning and comes late in the night. So I have not had adequate time with him........"

Another parent had this to say:

".........Though my child was not going to school, she was barely at home. I tried keeping her home with various chores but she always had her way to be away. She had a group of friends with whom she would spend her day.........."

It is clear from the quotes above that the parents/guardians did not have adequate time to be with their children and failure by parents to guide, monitor and advice the desired behavior to their children at the family level may be suggestive that the juveniles succumbed to their peers' pressure.

Only one parent said that she had adequate time for his child:

"......I was at home most of the time and I think we had spent adequate time together. I would have him work with me most of the time so that I could have a chance to guide him but still he adopted unacceptable behaviors......"

Parents/guardians did not have adequate time to be with their children and it implies less intimate relationships which creates suitable ground for a juvenile to commit delinquent acts. Demuth $\&$ Wright (2012) also founded that lack of parental control and lack of quality relationships between parents and children resulted in adolescent substance abuse and delinquent behavior. Still, this is confirmed by what juveniles reported in the questionnaire that $91 \%$ of the participants said that they did not receive enough follow up from their parents /guardians.

A look at the information contained in table 5 demonstrates that the juveniles spent most of their time with their female parent/guardian; the majority of them spent time with their mothers $43.75 \%$ and $17.5 \%$ with their grandmothers. Only $11.25 \%$ and $8.75 \%$ spent their time with their grandfathers and fathers correspondingly. A significant number (18.75\%) also spent most of their time with their friends. The average percentage of $61.25 \%$ (mothers, $43.75 \%$ and $17.5 \%$ grandmothers) of the juveniles who spent most of their time with female guardians/parents. This suggests that female parents/guardians were more available for the juveniles than the male parents/guardians. The findings also suggest that either the number of female-single headed families or the extent of the level of un-involvement in parenting by fathers in the study area is high. This is consistent with findings by Kimani and Kombo (2010) that fathers in contemporary society have left their parenting roles to mothers.

Table 6: Estimated Monthly Income and Family Size of Parents of the Respondents

\begin{tabular}{|c|c|c|c|c|c|}
\hline \multirow[b]{2}{*}{ S. No } & \multirow[b]{2}{*}{ Item } & \multicolumn{4}{|c|}{ Number of Respondents } \\
\hline & & Male & Female & Total & Percentage \\
\hline \multirow[t]{6}{*}{1} & \multicolumn{5}{|l|}{ Monthly Income of Parents of the Respondents } \\
\hline & less than 1000 Birr & 59 & 3 & 62 & 77.5 \\
\hline & 1001-5000 Birr & 5 & 4 & 9 & 11.25 \\
\hline & $5001-10000$ Birr & 3 & 3 & 6 & 7.5 \\
\hline & Greater than 10000 Birr per month & 2 & 1 & 3 & 3.75 \\
\hline & Total & 69 & 11 & 80 & 100 \\
\hline \multirow[t]{2}{*}{2} & \multicolumn{5}{|l|}{ Family size } \\
\hline & $1-3$ & 6 & 2 & 8 & 10 \\
\hline
\end{tabular}

This publication is licensed under Creative Commons Attribution CC BY.

http://dx.doi.org/10.29322/IJSRP.10.07.2020.p10356

WWW.ijsrp.org 


\begin{tabular}{|l|l|l|l|l|l|}
\hline & $4-6$ & 20 & 5 & 25 & 31.25 \\
\cline { 2 - 7 } & $>6$ & 43 & 4 & 47 & 58.75 \\
\cline { 2 - 7 } & Total & $\mathbf{6 9}$ & 11 & 80 & $\mathbf{1 0 0}$ \\
\hline
\end{tabular}

Source: Own Survey, 2017

Table 6 showed that the majority, $62(77.5 \%)$ parents of the respondents earned less than 1000 Birr per month. It further revealed that $9(11.25 \%)$ parents of the respondents were having monthly income of 1001 to 5000 Birr, 6 (7.5\%) earned between 5001 to 10,000 Birr per month and the rest $3(2.5 \%)$ parents of the juveniles earned greater than 10000 Birr per month. Here we see that the majority family's income is less than 1000 Birr per month. Therefore, it could be understood that juveniles who come from low family income are more likely to participate in delinquent behavior. This is consistent with findings by Wahab (2015) that youngsters from communities with lower income were moreat the highest risk of juvenile crime than those from upper-class communities. The lower the economic capability of an individual, family, or society contemplated the more risk chances of crime involvement.

concerning the family size the survey results show that $10 \%$ of respondents had a family size ranging from $1-3,31.25 \%$ of them had family members $4-6$, and the remaining $58.75 \%$ of them had more than 6 family members (Table 6). Though the largest families had the highest number of delinquents from the data we cannot conclude that as family size increase the prone for delinquency also increase. This is because parents of larger families who have substantial economic resources may be better able to meet their children's needs ina way that reduces the probability of delinquency. These results are similarto Prior's (2010) argument that a more important variable is economic resources rather than family size.

\section{Influence of External Environment}

The external family environment encompasses peers, school and the community, which influence juvenile delinquency.

Table 7: Peer pressure, Group involvement, and Alcohol or Drug abuse

\begin{tabular}{|c|c|c|c|c|c|}
\hline \multirow[b]{2}{*}{ S. No } & \multirow[b]{2}{*}{ Item } & \multicolumn{4}{|c|}{ Number of Respondents } \\
\hline & & Male & Female & Total & Percentage \\
\hline \multirow[t]{4}{*}{1} & \multicolumn{5}{|l|}{ Do you think Peer pressure leads you to withdraw from school? } \\
\hline & Yes & 45 & 6 & 51 & 63.75 \\
\hline & No & 24 & 5 & 29 & 36.25 \\
\hline & Total & 69 & 11 & 80 & 100 \\
\hline \multirow[t]{4}{*}{2} & \multicolumn{5}{|l|}{ Have you ever been engaged in any group of delinquents? } \\
\hline & Yes & 49 & 4 & 53 & 66.25 \\
\hline & No & 20 & 7 & 27 & 33.75 \\
\hline & Total & 69 & 11 & 80 & 100 \\
\hline \multirow[t]{4}{*}{3} & \multicolumn{5}{|l|}{$\begin{array}{l}\text { Do you think that the use of drugs or alcohol leads you to involve in } \\
\text { Delinquent acts? }\end{array}$} \\
\hline & Yes & 13 & 1 & 14 & 17.5 \\
\hline & No & 56 & 10 & 66 & 82.5 \\
\hline & Total & 69 & 11 & 80 & 100 \\
\hline \multirow[t]{4}{*}{4} & \multicolumn{5}{|l|}{$\begin{array}{l}\text { Do you think the availability of alcohol; drugs in the neighborhood } \\
\text { The influence you to utilize the drugs? }\end{array}$} \\
\hline & Yes & 38 & 5 & 43 & 53.75 \\
\hline & No & 31 & 6 & 37 & 46.25 \\
\hline & Total & & & & 100 \\
\hline
\end{tabular}

Source: Own Survey, 2017

Peer Pressure 
As far as the influence of deviant peers on school dropout is concerned the results have shown that $63.75 \%$ of the respondents mentioned that they dropped out of school due to peer pressure and the rest $36.25 \%$ of them were not influenced by their peers (Table 7). One of the delinquents indicated how peer influence had led him to withdraw from school:

“...........My parent sends me to school, but instead, I go with my friends to the bush, and in the afternoon when the children come from school, I come home ... I struggled a bit at school and it started at the time I began to associate with those my friends, that's when I started to perform poorly at school and eventually I dropped out of school........"

Peer influence was also given as a reason contributing to children dropped out of school by most of the parents. One of the parents had this to say:

"His friends with whom he associates are also school dropouts, and all of them use Drugs ..."

Similar remarks were given by one of the guardians. One of the guardians remarked:

"They associate themselves with the wrong friends and there is peer pressure"

The above views of the juveniles and their parents or guardians indicated that association with deviant peers has led to them underperforming or temporally expelled at school, which then in return resulted that they permanently dropped out of school. The findings suggest that peers and the people that the juveniles interacted with influenced their behavior. These findings are consistent with Dizon-Luna's (2013) argument that deviant peers cluster together and encourage one another to support the idea of dropping out of school. Therefore, absence from school is a fertile ground for delinquency.

\section{Group Involvement}

Most violent criminals belong to teenage peer-groups especially street gangs (Shaw, 2007:189). Clifford Shaw once uttered, "I never met a delinquent who acted alone". Most young people work together as the fact that they are of similar characteristics enabling them to manage their activities as far as their age vulnerability is concerned. It was realized that, $66.25 \%$ of young offenders were involved in a group of delinquents whereas $33.75 \%$ were not involved. Respondents identified reasonsfor their involvement in a group of delinquents saying they needed a substitute of the family as far as their urban life is concerned. Others stated that they did not want to be alone because belonging to a group provide protection within the neighborhood. Still, others stated that they want to depend on their group for survival. $56 \%$ of them said they were influenced by others to join their groups. These results are similarto UN-Habitat's (2004) argument that youth join gangs to get "a perceived" respect in a community, others band together for the purpose of finding community (street children) and work together.

\section{Alcohol and Drug abuse and Delinquency}

Kuo and Yang, (2002) argued that many delinquent acts appear to be committed while the perpetrator has been using drugs or alcohol. To confirm whether such a relationship existed in the context of this study, respondents were asked whether they had committed the offense for which they were institutionalized while under the influence of alcohol or drug. About $17.5 \%$ of the respondents reported that they committed the offenses under the influence of drugs or alcohol (see table 7). This reinforces report released by the national center on addiction and substance abuse (CASA) at Columbia University (2010), four of every five children and teen arrestees in state juvenile justice system are under the influence of alcohol or drugs while committing their crimes. Some of the key informants from especial representatives to juvenile delinquents at the correctional administration center also held similar views that offenders could use illegal substances such as drugs or alcohol to be brave enough to commit crimes. However, some of the informants from judges did not agree with this position. This is inferred from the response given below from one of the judges:

"Use of the illegal substance or alcohol abuse was a factor but to a lesser extent as a crime such as a bank robbery requires some great deal of planning and concentration."

From the above quotation, we can understand that the use of alcohol or illegal drugs has a causal link to delinquent acts. But this would depend mostly on what type of crime is to be committed.

\section{Influence of Availability of Alcohol and Drugs in the Neighborhood}

Respondents were asked whether they had utilized the alcohol or drugs out of the influence of their neighborhood. Out of $73.25 \%$ of the respondents' who are different drug users, the majority $(54 \%)$ of the respondents reported that they utilized alcohol and drugs out of the influence of their neighborhood in which alcohol and drugs were easily accessible to them (Table7). From the above data, we can understand that an environment proliferated with anti-social behaviors that may have encouraged undesirable behaviors among the juveniles. This finding is supported by Mincey et al. (2008) which showed that children in environments where they are exposed to criminal activities have a likelihood of emulating the behaviors because they consider them acceptable. Additionally, when respondents asked in what ways did the availability of drugs or alcohol influence them to utilize, $42 \%$ of respondents reported that with the uncontrolled expansion of venues serving addictive substances such as alcohol and khat in their neighborhood and they see people around enjoying it, make them want to try what it feels like to be drunk or, intoxicated. The findings are consistent with past studies by Plomin et al. (2006) which have shown that children who lived in social environments abounded with social evils are likely to emulate that behavior.

According to table 8, $59(73.75 \%)$ of the delinquents used different types of drugs. The remaining 21 (26.25\%) of the delinquents never used drugs.

Accordingly, cigarettes and khat are substances or drugs used at utmost among the delinquents 50 (62.5\%), 49 (61.25\%) respectively. Followed by alcohol 45(56.25\%), hashish $26(32.5 \%)$, shisha $16(20 \%)$ and the remaining $7(8.75 \%)$ accounts for other substances. The above table also indicates that out of 80 samples size of juvenile, 50 (62.5\%) were smokers, $49(61.25 \%)$ were accustomed to the habit of chat chewing, $45(56.25 \%)$ drunker, 26(32.5\%) were adducted to hashish and 16(20\%) of them were adducted to shisha and the remaining $7(8.75 \%)$ of them were addicted to other types of habits. The findings are similarto the past study by Sisay (2014) which has shown that out of 86 sample size of juvenile $44(51.16 \%)$ of the delinquents used 
different types of drugs. And $58(67.44 \%)$ of the juvenile were addictedto chat and alcohol for each, 56(65.11\%), $16(18.60 \%)$ and $13(15.11 \%)$ were addicted to cigarettes, hashish, and benzene respectively. $11(12.80 \%)$ were addicted to shisha and the remaining $9(10.50 \%)$ covers other drugs.

Table 8: Distribution of Respondents Personal Habit

\begin{tabular}{|c|c|c|c|c|c|}
\hline \multirow[b]{2}{*}{ S. No } & \multirow[b]{2}{*}{ Item } & \multicolumn{4}{|c|}{ Number of Respondents } \\
\hline & & Male & Female & Total & Percentage \\
\hline \multirow[t]{4}{*}{1} & \multicolumn{5}{|c|}{ Have you ever used substances/drugs? } \\
\hline & Yes & 52 & 7 & 59 & 73.75 \\
\hline & No & 17 & 4 & 21 & $26 . .25$ \\
\hline & Total & 69 & 11 & 80 & 100 \\
\hline \multirow[t]{8}{*}{2} & \multicolumn{5}{|c|}{ Kind of Drugs they use } \\
\hline & Khat & $42 *$ & $7 *$ & $49^{*}$ & 61.25 \\
\hline & Alcohol & $39 *$ & $6 *$ & $45^{*}$ & 56.25 \\
\hline & Cigarettes & $47 *$ & $3 *$ & $50^{*}$ & 62.5 \\
\hline & Hashish & $24 *$ & $2 *$ & $26^{*}$ & 32.5 \\
\hline & Shisha & $12^{*}$ & $4 *$ & $16^{*}$ & 20 \\
\hline & Others & $5^{*}$ & $2 *$ & 7 & 8.75 \\
\hline & Total & - & - & - & - \\
\hline
\end{tabular}

Source: Own Survey, 2017

*refers to more than one responses of respondents

\section{Typology of Crimes Committed by the Delinquents}

The study revealed that theft and related crimes are the mostly committed by juveniles than any other offense. Theft is the leading crime with $36.25 \%$ of all the crimes committed by respondents, robbery was committed by $17.5 \%$ of the respondents, a burglary was $15 \%$, a crime involving disorderly conduct or gambling was $10 \%$. Serious crimes such as murder were committed by $5 \%$ of respondents, attempt to killing $3.75 \%$, rape $8.75 \%$ and assault by $3.75 \%$ of respondents (Table 9 ). The fact that most of the respondents studied were institutionalized for economic-related crimes such as theft, robbery, burglary and gambling, as opposed to other offences is an indicator of the presence of poverty and social deprivation in the lives of these children. These results propose that many juveniles are in the struggle of having something for their basic need to sustain their life leading them to take peoples' belongings and property. Also, substance use acts as an attribute to stealing and theft for the sole aim of having money to buy drugs and relates substances. Information provided by key informants from judges indicated that theft crimes done by young offenders were to enable them to buy drugs.

Table 9: Types of Crimes Committed by Delinquents

\begin{tabular}{|c|c|c|c|c|c|}
\hline \multirow[b]{2}{*}{ S. No. } & \multirow[b]{2}{*}{ Item } & \multicolumn{4}{|c|}{ Number of Respondents } \\
\hline & & Male & Female & Total & Percentage \\
\hline \multirow[t]{6}{*}{1} & \multicolumn{5}{|c|}{ Typology of Crimes Committed by the delinquents } \\
\hline & Theft & 25 & 4 & 29 & 36.25 \\
\hline & Robbery & 11 & 3 & 14 & 17.5 \\
\hline & Burglary & 10 & 2 & 12 & 15 \\
\hline & Murder & 2 & 2 & 4 & 5 \\
\hline & attempt to killing & 3 & - & 3 & 3.75 \\
\hline
\end{tabular}




\begin{tabular}{|l|l|l|l|l|l|}
\hline \multirow{2}{*}{ Rape } & 7 & - & 7 & 8.75 \\
\cline { 2 - 7 } & Gambling & 8 & - & 8 & 10 \\
\cline { 2 - 7 } & Assault & 3 & - & 3 & 3.75 \\
\cline { 2 - 6 } & Other & 0 & & 0 & 0 \\
\cline { 2 - 6 } & Total & $\mathbf{6 9}$ & $\mathbf{1 1}$ & $\mathbf{8 0}$ & $\mathbf{1 0 0}$ \\
\hline
\end{tabular}

Source: Own Survey, 2017

\section{Factors for Criminal Behavior}

Criminality is one of the alarming world problems in looking up the effects, prevention, and solutions knowing the causes is paramount important. The causes and conditions for juvenile crime are usually at each level of the social structure. The study explored social causes that pushed young offenders in a correctional and rehabilitation center to involve in crime.

\section{Table 10: Social Causes for Committing Offenses}

\begin{tabular}{|l|l|l|l|l|l|}
\hline \multirow{2}{*}{ S. No. } & \multirow{2}{*}{ Item } & Number of Respondents & \multicolumn{2}{l|}{ Percentage } \\
\cline { 4 - 6 } & & Male & Female & Total & \\
\hline 1 & Social factors for committing offenses & & & & \\
\hline & Economic problem /poverty & 21 & 4 & 25 & 31.25 \\
\cline { 2 - 6 } & less intimate relationship with parents / integration & 6 & 2 & 8 & 10 \\
\cline { 2 - 6 } & Broken family (divorce, death of one parent or both, migration) & 11 & 1 & 12 & 15 \\
\cline { 2 - 6 } & Peers influence & 19 & 2 & 21 & 26.25 \\
\cline { 2 - 6 } & use of alcohol, drugs & 12 & 2 & 14 & 17.5 \\
\cline { 2 - 6 } & Other & 0 & 0 & 0 & 0 \\
\cline { 2 - 6 } & Total & $\mathbf{6 9}$ & $\mathbf{1 1}$ & $\mathbf{8 0}$ & $\mathbf{1 0}$ \\
\hline
\end{tabular}

Source: Own Survey, 2017

The study results demonstrate that $31.25 \%$ of respondents involved in deviant acts due to economic problems or poverty, $26.25 \%$ became delinquents on their peer influences, $17.5 \%$ of the respondents in state of alcohol intoxication they end up in delinquent acts thus conflicting with the laws. The UN (2003) states that the use of alcohol and illegal drugs by young people is one of the delinquency as they involve in petty theft to acquire the cash for the purchase of substance use. Other social factors were broken family (divorce, death of one parent or both, migration) and less intimate relationship or integration with their parents (Table 9). The finding fact that the high proportion of minors involved in deviant acts lure for economic reasons is supported by Manh (2013) that if a family has unstable finances children may resort to adopting a socially defective approach to meet their needs. And this fact is implicated by the differential opportunity theory of Cloward and Ohlin (1960) which argues that poverty of the lower classes prevents them from using legitimate means, such as education, to acquire valued goods, thus giving them no alternative but to engage in illegitimate activities.

Additionally, on interviewing parents/guardians about social causes that led them to take their children for correctional and rehabilitation centers, most of them expressed their disappointment in their socio-economic status because making ends meet appears very difficult for them. The extracts below explain some of their views. For example, one of the delinquent parents expressed as follow:

“.......Life has become hard. I cannot afford three meals a day for my children. A light breakfast and supper are all I can afford." Another one said, "My children are only assured of tea in the morning and supper. Lunch is never guaranteed but we are used."

From the above quotation we might understand that the juvenile's parent/guardian did not provide the basic needs of their children failed to do so the juveniles could attract involvement in delinquent acts such as stealing related offenses that had led the majority of the juveniles to be placed in correctional and rehabilitation center.

Key informants interviewed on whether or not the economic problem was a factor influencing crime indicated the following. The police inspector said, "Poverty is really a main factor in crime commission as people are frustrated when their income doesn't meet the basic needs of the family, they could commit crimes such as theft." 
To summarize data collected through key informant interviews, among the questions asked, questions related to who mostly involved in crimes between men and women juvenile, most of the informants responded that men mostly involved in crimes than women. Regarding the social causes for becoming delinquent, the majority of the respondents identified poverty or economic problem as the main cause for juveniles to involve in delinquency. The other reason raised by the majority of the respondents as the cause for juveniles to involve in delinquency was peer pressure. Other social causes identified by the key informants for juveniles to start involving in delinquent actions were dysfunctional families, lack of parental control and close relationships with their parents, rural-urban migration, and use of alcohol or drug abuse. Most of the respondents from the police investigators, judges, delinquent parents, and special representatives to juvenile delinquents at the correctional administration center agreed that theft was most committed by juveniles.

\begin{tabular}{|l|l|l|l|l|l|}
\hline \multirow{2}{*}{ Item } & \multicolumn{4}{l|}{ Number of Respondents } \\
\cline { 3 - 7 } & Male & Female & Total & Percentage \\
\hline Do you believe you can abandon this delinquent behavior? & 65 & 8 & 72 & 91.25 \\
\hline Yes & 4 & 3 & 7 & 8.75 \\
\hline No & $\mathbf{6 9}$ & $\mathbf{1 1}$ & $\mathbf{8 0}$ & $\mathbf{1 0 0}$ \\
\hline Total & & & \\
\hline
\end{tabular}

Futurities of delinquents

Table 11: Do you believe you can abandon this delinquent behavior?

Source: Own Survey, 2017

Futurity means the chance of juveniles continuing their delinquent behavior or quit their delinquent action. When that asked the participants their futurity $91.25 \%$ of respondents saying promised to abandon their delinquent behavior when they are out of the correctional center. They saying it has been one of the difficult and discouraging moments of their life. They aired out as they got lessons from their previous deeds and the rest $8.75 \%$ of respondents said they could not abandon their delinquent behavior because to them it is the means of their survival. The findings are in support of Betelehem (2014) who have shown that out of 41 sampled delinquents $36(87.80 \%)$ of the respondents believe that they can abandon their current delinquent behaviors, while the rest $5(12.2 \%)$ of the delinquents do not believe that they can abandon their involvement.

\section{Future plan}

The results imply that education provided by the correctional and rehabilitation has positive effects on the young offenders. At least some individuals are able to come up with plans on what will they be doing to earn for the living as one of the ways of ensuring they are not back in criminality. $45 \%$ of the respondents were to employ themselves in different activities using training skills gained while serving their sentence, $43.75 \%$ said they will avoid any person with bad influence and other temptations like alcohol or drug. However, $11.25 \%$ of respondents did not have any plan in their mind at the time of survey stating that they don't know what awaits them after prison hence they will figure out when they are out (Table 12).

Table 12: Strategies to be used by the respondents to avoid crimes

\begin{tabular}{|l|l|l|l|l|l|}
\hline \multirow{2}{*}{ Item } & \multicolumn{4}{l|}{ Number of Respondents } & \multicolumn{4}{l|}{ Percentage } \\
\cline { 3 - 6 } & Male & \multicolumn{2}{l|}{ Female } & Total & \multicolumn{5}{l|}{} \\
\hline Plans to be used by the respondents to avoid crimes & 33 & 3 & 36 & 45 \\
\hline Working to earn money & 30 & 5 & 35 & 43.75 \\
\hline Avoid delinquent friends and other temptation & 6 & 3 & 9 & 11.25 \\
\hline I don't know & 6 & $\mathbf{1 1}$ & $\mathbf{8 0}$ & $\mathbf{1 0 0}$ \\
\hline Total & $\mathbf{6 9}$ & & \\
\hline
\end{tabular}

Source: Own Survey, 2017

Respondents' view on the correctional and rehabilitation center

Respondents were asked to say if the correctional and rehabilitation center was able to change their behavior to socially accepted behaviors and actions. In this regard, the study revealed that most of the respondents $68 \%$ were happy and satisfied by the training, vocational skills and counseling. About $30 \%$ of respondents said that the correctional and rehabilitation center efforts were not enough while $2 \%$ said they were not happy with whatever was done by the correctional and rehabilitation center. The correctional center's efforts were not enough because 
juveniles were not incarcerated based on their offence type, number of times incarcerated and age group. According to them, Because of this, they are learning different criminal techniques from their mates in the center. This is confirmed by the information provided by one of the special representatives of juvenile delinquents (counselor) in correctional and rehabilitation center through interview stated as follow:

"........... They are locked in the same room, whether he/she is little or not. So, what do you expect? They will share each other's different skills. If one knows only how to steal money from pocket, he/she will learn here how to rob from a house--- after that they will be released from the center learning more skills from senior criminals. To avoid this influence, they have to be placed in different rooms according to their age or offence type or whatever to reduce the influence. But to do this we do not have financial capacity........."

To summarize, male adolescents are more involved in most types of delinquent behavior than female adolescents. In the case of age the majority of the respondents were aged between 13-17 years. This indicates that involvement in delinquency changes with age during adolescence. The study generally has found that migrant juveniles are mostly involved in delinquent behaviors. The study also found that most of the juveniles in correctional and rehabilitation centers are from orthodox Christianity religious followers. Concerning the educational level of the delinquents, the study showed that majority of the juvenile offenders in Axum correctional and rehabilitation centers characterized by a low level of education. Finally, gender, religious background, place of origin and level of education are demographic characteristics linked to delinquency. Some of the family environment possible explanations for delinquency in this study were: Dysfunctional families, quality in family relationships and Lack of parental control, large family size and Low family socioeconomic status. All of these social causes forced the juveniles to commit delinquent acts. In addition, the study realized that most of the young offenders were involved in a group of delinquents and they were influenced by others to join their groups. The results further demonstrate that quite a good number of the respondents used drugs or alcohol out of the influence of their neighborhood. In turn, use of drugs or alcohol and addiction to different types of substances pushes the young to participate in delinquent behavior. Findings concerning the types of crimes committed by the delinquents, the study found that the majority of the delinquents were entering to correctional center by theft and stealing related crimes. This study revealed that the main cause that pushes the juveniles towards delinquency is poverty and association with delinquent peers. Generally, the study found that family relations and external environment as social causes drive the juveniles to delinquency.

\section{CONCLUSION}

The first objective of this study was to investigate the demographic characteristics of juvenile delinquents such as their sex, religious background; age of the juveniles while they joined the correction center, their place of origin, their highest level of education. With regard to sex, the results of the study showed that most offenders who committed a crime in Axum were men. concerning age, the result of the study indicates that the delinquents belong to the age group of 13-17 years were more probable to commit crimes as compared to those with adolescents ages. With respect to religious background, the research result found that $91.25 \%$ of the respondents were followers of the Orthodox Christianity religion. The study also found that most of the offenders were juveniles who come from rural areas and who had poor family background is more like to commit a different offense in the adolescence period. The results of the study indicate that young people in lower education levels were more involved in criminal activities.

The second objective was to identify the social causes of juvenile delinquency in the study area. The study revealed that those who live in two-parent families were found less likely to involve in juvenile crimes as compared to those living in dysfunctional families. The study also found that a higher rate of delinquency among those youth who lack parental control and close relationships with their parents, compared to others. The study shows that juveniles who were from large-sized /or lowincome families commit delinquent acts than smaller sized and higher-income families. The results further demonstrate that quite a good number of the respondents have at some point in time used drugs or alcohol out of the influence of their neighborhood. This signifies that easily accessibility of alcohol or drugs to juveniles and the use of drugs or alcohol, the higher the chances of engaging in delinquent behaviors. The study found out that most respondents were members of the delinquent groups and spend most of the time with their friends which result in dropping out of school which allows them to have criminal ways of thinking. The study indicates that economic problems or poverty are the main reason for many juvenile's involvement in crimes. It can also be recalled that economic-related crimes such as theft, robbery, burglary, and gambling were the offices that had led the majority of the juveniles to be placed in correctional and rehabilitation centers. The findings of this study also show that a significant number of juveniles were institutionalized out of peer influences. In the research study two theories i.e. Cloward and Ohlin's differential opportunity theory and Sutherland Differential Association Theory were found the most suited to explain the phenomena of juvenile delinquency. Differential opportunity theory argues that poverty of the lower classes prevents them from using legitimate means, such as education, to acquire valued goods, thus giving them no alternative but to engage in illegitimate activities. This theory has a close association with this research finding. The Differential Association Theory also deals with young people in a group context and looks at how peers influence and the existence of gangs could lead them into crime. The theory is very much in consonance with this research finding because the study found that peer group has a social influence on juveniles' behavior, most of the respondents reported that they spend most of the time with their friends and also blamed them for their delinquent behavior. However, other social factors i.e. dysfunctional families, large family size, rural-urban migration, quality in family relationships, lack of parental control and use of drugs or took alcohol were social causes found that influence these young into crime and delinquency.

The final objective was to identify crimes committed by convicted juveniles. The study found that theft was the leading crime committed. Other crimes were robbery, burglary, gambling, 
and rape. Assault, attempt to killing, and murder were also reported though not in high percentages.

On the basis of the findings and conclusions of the study the researchers are extending the following suggestions to decrease the increasing rate of juvenile delinquency in the study area.

\section{RECOMMENDATIONS}

$>$ Increase the income of rural people. It was found during the research study that most of the respondents were compelled by poverty and financial problems to commit heinous crimes so the agricultural sector should be attractive enough that the incomes of rural people enable them to run their lives which include fulfilling their children material needs. Together with this, the government should provide adequate employment opportunities from non-agricultural activities such as small industry, co-operatives in rural areas to diversify their source of income. This will encourage young people to run their lives there thus lowering the intensity of ruralurban migration.

$>$ Birth control education should be given to the public members as many parents fail to accommodate the needs of children due to the high number of children. Family populated by children and young people most of them being idle as parents cannot afford material needs, children drop out from school and spending most of their time with peer groups the juveniles have involved in antisocial behavior substance use, violence and crimes included.

$>$ Dysfunctional families, weak control and loose bond of parents over their children and peer pressure are also found to be social factors for juveniles to become delinquents. Thus, parents should avoid divorce because it could lead them to engage in delinquent acts. Also, they must have a close relationship with their children and the parents should be aware of the activities that their children are engaged in and they should also know who are the friends of their children and what they do together to counter the evil impact of the peer pressure that influence these young into crime and delinquency.

$>$ There is a need to have stringent measures in place against people who break the law prohibiting the selling of alcohol or drug to children and barring them from entering venues serving addictive substances. This might help reduce cases of the juvenile's early exposure to alcohol or drug abuse.

$>$ Both juvenile delinquents and adult criminals were institutionalized to the same correctional center but this situation may create opportunists for juvenile delinquents to learn other criminal activities and techniques from each other and adult criminals. Therefore, juveniles should institutionalize based on their types of criminal activities and age groups. Also, the government should have established remand home for juvenile delinquents at least at the regional level.

$>$ The police investigators and judges should work hand-inhand with the community as a whole in fighting juvenile delinquency and crime.

\section{REFERENCES}

[1] Agnew, R. (2008). Story lines as a Neglected Cause of Crime.Journal of Research in Crime

[2] Alemika.(2008). Juvenile Justice Administration in Nigeria: Philosophy and Practice Centre for

[3] and Delinquency 43:119-47.

[4] Andargachew, T.(2004). The Crime Problem and its Correction.Addis Ababa University Press.

[5] Apel,R., \&Kaukinen. (2015). On the relationship between family structure and antisocial behavior: Parental cohabitation and blended households. Criminology, 46, 35-70.

[6] Astone, N.M. \&McLanahan, S.S.( 2012). Family Structure, Residential Mobility, and SchoolDropout: A Research Note. Demography, 31: 575-584.

[7] Azeb, A. (2009). The Addis Ababa rehabilitation Institute for Juvenile Delinquents; Institutional Capacity Needs Assessment Survey Reports.The Addis Ababa Social and Civil Affairs Bureau and Forum on Street Children Ethiopia. Law Enforcement Education Lagos, Nigeria.Vol.2.

[8] Barrett, T. M. (2010). Cognitive, environmental, and familial mediators and moderators between exposure to violence and adolescent delinquency.Psi $\mathrm{Chi}$ Journal of Undergraduate Research, 12(2): 59-69.

[9] Benekos, P. J. \& Merlo, A. V. (2010).Controversies in Juvenile Justice and Delinquency(2nd Ed.).Cincinnati, OH: Anderson/LexisNexis.

[10] BezuidenhoutFJ( 2004). A Reader in Selected Social Issues. Pretoria: Van Schaik Publishers.

[11] Bimal, Kanta N.(2013). Juvenile Delinquency: Its Magnitude and Impact at Gondar town in Ethiopia. Journal of Management and Social Sciences Vol.2.Retrieved from (http://www.irjcjournals.org/ijmssr/)

[12] Bryman, A. (1988). Quantity and Quality in Social Research . New York : Teylor and Francis.

[13] Cameron L. SL.Wise\& SM Lott ridge. (2007).The Development and Validation of the Information Literacy Test. College and research libraries 68 (3):229.

[14] Center on Addiction and Substance Abuse (CASA) News Release. (2010). Most of juvenile offenders use drugs, alcohol. Retrievedfrom http://alcoholism.about. Com/od/teens/ /blcasa041007.htm

[15] Central Statistical Agency.(2015). StatisticalReport on the 2015 Urban Employment UN Employment Survey. Addis Ababa: Central Statistical Authority.

[16] Cloward, Ohlin L. (1960). Delinquency and Opportunity: A Theory of Delinquent Gangs, Glencoe: Free Press.

[17] Cohen AK .(1955). Delinquent Boys: The Culture of the Gang, Glencoe. IL: Free Press.

[18] Comanor, W.S., \& Phillips, L. (2012).The impact of income and family structure on delinquency.Journal of Applied Economics, 5, 209-232.

[19] Crawford and Lizabeth .(2013). Parent Child Relations and PeerAssociations as Mediators of the Family Structure Substance Use Relationship.Journal of Family Issues.Pg. 155-184.Retrieved from http://jfi.sagepub.com.ezproxy.lib.calpoly.edu.

[20] D'Cruz\& Jones.(2007).Social Work Research in Practice, Ethical and Political contexts. (2ndEd.).RMIT University, Melbourne.Sage.

[21] David, J.H. (2006). Delinquency and Crime: current theories, Cambridge: Cambridge university.

[22] De Coster and Heimer.( 2013). Neighborhood disadvantage, social capital, street context, and youth violence. The Sociological Quarterly, 47(4): 723753.

[23] Dekovic, M., Janssens, J., \& Van-As, N.( 2015). Family predictors of antisocial behavior inadolescence.Family Process, 42(2), 223-235.

[24] Delbert Elliot, Ageton and R.J. Canter. (1985).An Integrated Theoretical perspective on Delinquent Behavior, Journal of Research in Crime and Delinquency 16(1):3-27. 
[25] Demuth, S. \& Brown, S.L. (2012). Family Structure, Family Processes, and Adolescent delinquency: The Significance of Parental Absence versus Parental Gender. Journal of research in Crime and delinquency, 41:58-81.

[26] Dizon-Luna, S.R.T. (2013). Failure to Stay in School: A Study of Female Adolescent dropout.Journal of Arts, Science and Commerce, IV (2):81-86.

[27] Dodge, K. A. Dishion, T. J. \& Lansford, J. E. 2011. Deviant peer influences in programsfor youth. New York: Guilford. Retrieved fromhttp://www.ncbi.nlm.nih.gov.

[28] Edwin, M. (2006).Human deviance, social problem and social control. New Jersey: Prentice-Hall, Inc.

[29] Emeka, Obioha, and Mapholoana.(2012). Social Background Patterns and Juvenile delinquency: A Case Study of Juvenile Delinquents in Nexus in Lesotho.

[30] Fagan \& Arthur.(2014). Using community and family risk and protective factors for community-based prevention planning.Journalofcriminology ,35(4): 535-555.

[31] Federal police commission.(2014).National crime statistics, Addis Ababa, Ethiopia.

[32] Fekede, T. (2010). The Basics of Distinction between Qualitative and Quantitative Research in Social Science: Reflection on Ontological, Epistemological and Methodological Perspectives. Ambo: Ambo University.

[33] Free, M. D. (2015). Clarifying the relationship between the broken home and juvenile delinquency: A critique of the current literature.Deviant Behavior, 12, 109-167.

[34] Furstenberg \&Teitler. (2015). Reconsidering the Effects of Marital Disruption:What happens to Children of Divorce in Early Adulthood? Journal of Family Issues, 15(2):173-190.

[35] Georges, S. (2009). Deviant Behavior and Violence in Luxembourg Schools.InternationalJournal of Violence and School, 54-70. Retrieved fromwww.ijvs.org/

[36] Granic, I. \& Patterson, G. R.( 2009). Toward a comprehensive model of antisocial development: A dynamic systems approach. Psychological Review, 113: 101-131.

[37] Haapasalo, J. \& Tremblay, R.E. (2014). Physically aggressive boys from ages 6 to 12: Family background, parenting behaviour, and prediction of delinquency. Journal of Consulting and Clinical Psychology, 62:1044-1052.

[38] HabtamuMamo. (2007). Assessing the pattern and trends of crime against the women prison. The case of Addis Ababa rehabilitation Institute for Juvenile Delinquents.MA Thesis.Addis Ababa University. Addis Ababa.

[39] Hammond and Linton. (2015). Dropout Risk Factors and Exemplary Programs: A TechnicaReport.Clemson, SC: National Dropout Prevention Centre, Communities in Schools, Inc.

[40] Harris, I. B. (2006). Children in jeopardy can we break the intergenerational poverty? Herbert Gintis, Family Background and Economic Success. New York: Princeton University Press.

[41] Hunte, M.( 2014). A Qualitative study of Delinquency and Achievement among LowIncome Youth in Trinidad. A Paper presented at SALISES 7th Annual Conference.University of West Indies, Cave Hill, Barbados.

[42] Ignacio, Munyo. (2013).Youth Crime in Latin America .Key Determinants and Effective Public Policy Responses.Economic and Social Policy in Latin America Initiative, Brookings Global-CERES.Incompetence and behavioral/emotional problems.Drug and Alcohol Dependence.

[43] Ingram andPatchin. (2014). Family life, peer associations, and serious delinquency: A path Analysis. Unpublished paper, Michigan State University.

[44] Israel, G.D. (1992). Sampling the Evidence of Extension Program Impact, Program Evaluation and Organizational Development, IFAS, University of Florida.PEOD

[45] Jarjoura, G.R.,Triplett, R.A. \& Brinker, G.P. (2012). Growing up poor: Examining the link between persistent childhood poverty and delinquency. Journal of Quantitative Criminology, 18(2): 159-187.

[46] John \&AndargatchewTesfaye .(2004).Child Welfare issues in Ethiopia: Sage Publications

[47] John,Onyango,Gerald O. Ondiek, OdhiamboOdera .(2013) Factors Influencing Youth Crime andJuvenileDelinquency, International Journal of Research in Social Sciences.University of Nairobi, Kenya.

[48] Juby\& Farrington, D.P. (2013). Disentangling the link between disrupted families andDelinquency. British Journal of Criminology, 41, 22-40.
[49] Keating. (2008).Approaches and Methodologies in the Social Sciences:A Pluralist Perspective.New York,Cambridge University Press.

[50] KebedeTadese.( 2008).The Legal Regime Related to Juvenile Delinquency in Addis Ababa: St. Mary's University College, Addis Ababa, Ethiopia.

[51] Kierkus, C.A., \& Hewitt, J.D. (2012).The contextual nature of the family structure /delinquency relationship.Journal of Criminal Justice, 37, 123-132.

[52] Kierkus, C.A., Johnson, B.R., \& Hewitt, J.D. (2010).Cohabitating, family and community stressors, selection, and juvenile delinquency.Criminal Justice Review, 35(4), 393-411.

[53] Kimani, E. \&Kombo, K. (2010). Challenges facing nuclear families with absent fathers in Gatundu North district, Central Kenya.An Online Journal of the African Educational Research Network, 10 (2)

[54] Kuo, P., Yang, (2002). Substance use among adolescents in Taiwan: associated personality traits,

[55] Lauer RH. (1998). Social Problems and the Quality of Life.McGraw-Hill.

[56] Leedy PD \&Ormrod JE.(2005). Practical research: planning and design.8th edition. Upper Saddle River, NJ: Pearson.

[57] Legal and Human Rights Centre, (2012).The State of Juvenile Crimes in Tanzania: A Fact finding Report on Legal and Practical Considerations. Report on the Findings of the research on Administration of Justice in Tanzania. pp. 5-54

[58] Leiber, M.J., Mack, K.Y., \& Featherstone, R.A. (2009). Family structure, family processes,economic factors, and delinquency. Youth Violence and Juvenile Justice, 7 (2), 79-99.

[59] Lipsey, M. W. \&Derzon, J. H. (2008). Predictors of violent or serious delinquency in adolescence and early adulthood: a synthesis of longitudinal research. Thousand Oaks.CA: Sage.

[60] Mack, Kristin Y. (2014). Reassessing the family-delinquency association: Do family type, family processes, and economic factors make a difference? Science Direct Journal of Criminal Justice, Vol. 35, Issue 1.Retrieved fromhttp://www.sciencedirect.com.ezproxy.lib.calpoly.edu.

[61] Manh, N.D. (2013). Role of families in educating spoiled children in Hanoi Unpublished doctoral dissertation.Vietnam National University, Hanoi.

[62] Manning, W.D., \& Lamb, K.A. (2013).Adolescent well-being in cohabitating, married, andsingle-parent families. Journal of Marriage and Family, 65, 876-893.

[63] Matt, H. M. (2006). A Short Introduction to Social Research . New Delhi: Sage Publications.

[64] Mc Neill, P. A. (2005). Research Methods . New York: Routledge .

[65] McCord, J. (2014). Family relationships, juvenile delinquency, and adult criminality.Criminology, 29, 397-417

[66] Merton RK. (1957). Social Theory and Social Structure: New York, Free Press of Glencoe.

[67] Mesafint, Adal. (2009). Juvenile Delinquency and Its Treatment: A Study on Addis Ababa Juvenile Delinquents Rehabilitation Institute. MA Thesis.Addis Ababa University. Addis Ababa.

[68] Miller and Brewer. (2003).The A-Z of Social Research: London, Sage.

[69] Mincey, B. Maldonado, N., Lacey, C. H., \& Thompson, S.D. (2008). Perceptions of successful graduates of juvenile residential programs: Reflections and suggestions for success. Journal of correctional education, 59(1) 8-31.

[70] Mugenda, O and Mugenda, G. (1999).Research Methods.Qualitative and Quantitative Approaches. Nairobi: African Centre for Technology Studies.

[71] NegaJibat and BerhanuNigussie (2015) Criminality and Victimization in Oromia, Ethiopia: Analysis of 2011/2012 Police Data. Sage.

[72] Ngale, F.I. (2011). Family structure and juvenile delinquency: Correctional Centre Betamba, Centre Province of Cameroon. Retrieved from http://www.internetjournalofcriminology.com/

[73] Ojo, M.O.D. (2012) A Sociological Review of Issues on Juvenile Delinquency the Journal of International Social Research Volume: 5 Issue: $21 \mathrm{pp} 465-482$

[74] Olotuah, A. O. \&Adesiji, O. S. (2009).Housing Poverty, Slum Formation and Deviant Behavior.Akure, Federal University of Technology Press.

[75] Paylor, I.( 2010). Understanding youth offending: Risk factor research, policy and practice. Child \& Family Social Work, 15(1): 131-133.

[76] Petts, R.J. (2009). Family and Religious Characteristics' Influence on Delinquency Trajectoriesfrom Adolescence to Young Adulthood.American Sociological Review. 74: 465-483. 
[77] Price, C., \& Kunz, J. (2013). Rethinking the paradigm of juvenile delinquency as related todivorce. Journal of Divorce and Remarriage, 3, 109133

[78] Prior, D. \& Paris, A. (2010) Preventing Children's Involvement in Crime and Anti- Social Behavior: A literature Review apaperproduced for the National Evaluation of theChildren'sFundInstitute of Applied SocialStudies University of Birmingham.

[79] Ramiro, M., \& Matthew, T. L. (2012).On immigration and crime.Volume 1.

[80] Richman, J.M., Bowen, G.L. \& Woolley, M.E. (2014). School failure: An eco-interactional developmental perspective. In M.W. Fraser (Ed). Risk and Resilience in Childhood: An Ecological Perspective.(2nd Ed), 133-160. Washington, DC: NASW Press.

[81] Russell, M, Harris B, Gockel, A. (2009). Parenting in poverty: Perspectives of high-riskparents. Journal of Children and Poverty, 14:83-98.

[82] Sandstrom, M. J.( 2012). A link between mothers' disciplinary strategies and children's relationalaggression. British Journal of Developmental Psychology, 25, 399-407.

[83] Sanidad-Leones, C. V. (2012). Current Situation of Crime Associated with Urbanization: Problems Experienced and Countermeasures Initiated in the Philippines. National Criminal Justice 68: 133-150

[84] Selamawit .T. (2014).Exploring the lived experience of delinquents and young offenders: The case of Addis Ababa police commission prisoners. M.A. Thesis. Addis Ababa University, Addis Ababa, Ethiopia.

[85] Shaw CR, McKay HD .(1942). Juvenile Delinquency in Urban Areas. Chicago: University of Chicago Press.

[86] Shaw, M. (2007).Comparative Approaches to Urban Crime Prevention Focusing on Youth.International Centre for the Prevention of Crime Thematic Analysis Report.16 pp.

[87] Siegel, Larry J.; Welsh, Brandon.(2011). Juvenile Delinquency. The core (4th ed.) Belmont, CA: Wadsworth/oengage Learning.

[88] Simoes. (2015). Juvenile delinquency: Analysis of risk and protective factors using quantitative and qualitative methods. An Interdisciplinary Journal, 12: 389-408.

[89] Simons, and Wallace, E. (2011).Families, delinquency, and crime: Linking society's most basic Institution to antisocial behavior. Los Angeles: Roxbury.

[90] Sisay, Zegeye. (2015). Causes of JuvenileDelinquency: A Case of Lideta Sub-City Administration Remand and Rehabilitation Center of Addis Ababa, Ethiopia.

[91] Sprague, J., \& Walker, H. (2013).Early identification and intervention for youth with antisocialand violent behavior.Exceptional Children, 66 (3): 367379.

[92] Sullivan, C.J.( 2010). Early adolescent delinquency: Assessing the role of childhood problems, family environment, and peer pressure. Youth Violence and Juvenile Justice, 4(4), 291- 313.

[93] Sutherland E. (1939). Principles of Criminology. Philadelphia: J.B. Lippincott.Tshwane University of Technology, Pretoria, South Africa.

[94] Urban Management Programme. (2012) .Street Children and Gangs in African cities: guidelines for Local authorities, Working Paper Series, No. 18.

[95] Warr, M. (2011).Companions in crime: The societal aspects of criminal conduct. Cambridge: Cambridge University Press.
[96] Weijters, G. (2013). Youth Delinquency in Dutch Cities and Schools: A multiple approach. Ipskamp Nijmegen Print Partners, Hertogenbosch. 149pp.

[97] Wickliffe \& Joseph A. (2013). Why Juveniles Commit Crimes. Yale-New Haven Teachers Institute. Retrieved from http:// www.Yale.edu/ynhti .com/

[98] Wikstrom and Oberwittler. (2012) .Breaking Rules: The Social and Situational Dynamics of Young People's Urban Crime. Oxford: Clarendon Press.

[99] Williams PF, McShane DM. (2004). Criminological Theory. United States of America: Pearson Education Inc.

[100]Wood, J., \&Alleyne, E. (2010). Street gang theory and research: Where are we now and wheredo we go from here? Aggression and Violent Behavior, 15: 100-111.

[101]Wood, J.J., Repetti, R.L. \&Roesch, S.C. (2009). Divorce and Children's Adjustment Problemsat Home and School: The Role of Depressive/Withdrawn Parenting, Child Psychiatry and Human Development, 35 (2): 131.

[102]Wright, B.R.E. \&Younts, C.W.(2009) .Reconsidering the Relationship between Race and Crime: Positive and Negative Predictors of Crime among African American Youth Journal of Research in Crime and Delinquency 46: 327.

[103] Yamane T. (1967). Statistics, an Introductory Analysis. 2nd, New York: Harper and Row.

[104]Zhang, D., Willson, V., Katsiyannis, A., Barrett, D., Ju, S. \& Wu, J. (2014). Truancy offenders in the juvenile justice system: A multi cohort study. Behavioral Disorders, 35(3),229-242 .

\section{AUTHORS}

First Author - Tekelwoyni Tesfamichael, Gondor University Department of Sociology, School of Sociology and Social Work, College of Social Science and Humanities, Ethiopia

Email: - tekelwoyni@gmail.com, +251914291829

\section{Second Author - Tesfaye Zeleke (Assistant Professor in} Sociology), Email:tesfayezeleke@gmail.com , Tel +251973 16 86 81, Addis Ababa University, College of Development Studies, Center for Environment and Development, Tourism Program

Third Author - Yonas kidane, College of Environmental Science and Engineering.Tongji University, Shanghai 200092, P.R. China., Email:- hizyonas @ gmail.com, Tel +8619946255103, +251914788209

Correspondence Author - Tesfaye Zeleke (Assistant Professor in Sociology) Email:tesfayezeleke@ gmail.com , Tel +251973 168681 